OPEN ACCESS

Edited by:

Abílio Afonso Lourenço, University of Minho, Portugal

Reviewed by:

Sergio Alexis Dominguez Lara,

University of San Martín de

Porres, Peru

Natalio Extremera,

University of Málaga, Spain

*Correspondence:

Ana M. Cristóvão alc@uevora.pt

Specialty section

This article was submitted to

Educational Psychology,

a section of the journal

Frontiers in Education

Received: 14 August 2019

Accepted: 23 December 2019

Published: 21 January 2020

Citation:

Cristóvão AM, Candeias AA and

Verdasca JL (2020) Development of Socio-Emotional and Creative Skills in

Primary Education: Teachers Perceptions About the Gulbenkian XXI School Learning Communities Project.

Front. Educ. 4:160

doi: 10.3389/feduc.2019.00160

\section{Development of Socio-Emotional and Creative Skills in Primary Education: Teachers' Perceptions About the Gulbenkian XXI School Learning Communities Project}

\author{
Ana M. Cristóvão*, Adelinda A. Candeias and José Lopes Verdasca \\ Research Center in Education and Psychology, University of Évora, Évora, Portugal
}

In recent decades, several authors have warned of the need to equip students with skills that include critical thinking, creativity, and emotional management. Emotions can facilitate or impede children's academic engagement, commitment, and ultimate school success since relationships and emotional processes affect how and what we learn. Teachers are the main emotional leaders of their students, and the foundation for promoting emotional balance within their groups is their ability to recognize, understand, and manage their emotions. The SEL approach defends that, as with academic skills, the development of social and emotional skills must be accomplished through explicit instruction. In the academic year 2014/2015, three schools in the Portuguese region of the Alentejo began an innovative 4-year project to promote change in learning. The main goal was to improve learning by promoting the acquisition of basic knowledge within the formal curriculum and to stimulate the development of analytical and practical reasoning skills, resilience and responsibility, as well as technological, emotional, social and creative skills. To this end, the research team created two programs to be developed in primary school, the Emotional Literacy Program (ELP) and the Creative Thinking Development Program (Flow) as well as a training program for teachers, Mediators for Well- Being Program. This article details a study analyzing the perceptions of primary school teachers who participated in the project. Data were collected by interviews and teachers' reflections were analyzed. Content analysis was chosen as the analytical technique as it is appropriate for treating qualitative data. The results show very positive impacts on the professional and personal development of teachers. Teachers reported improvements in student behavior, in the relationships between them and in the classroom environment. They further emphasized the need for teachers to receive more training in emotional education in their academic and in service education.

Keywords: teachers' perceptions, SEL programs, continuous teachers training, twenty-first century skills, well-being 


\section{INTRODUCTION}

It would be hard, we would go so far as to say almost impossible, to find a text on key skills for the twenty-first century that fails to mention the rapid advance of science and technology, the swift rate of social change, and the unpredictability that the future holds. We cannot, in fact, remain oblivious to these factors, as many of the students who attend our schools today will have jobs that have not yet even come into existence (World Economic Forum, 2016). Schleicher (2018) states that the educational community's greatest dilemma is that cognitive skills, which, he argues, are the easiest to teach and test, are those which, in turn, "that are also easiest to digitize, automate and outsource" (p. 231). The author states:

schooling today needs to be much more about ways of thinking (involving creativity, critical thinking, problem solving and judgement), ways of working (including communication and collaboration), tools for working (including the capacity to recognize and exploit the potential of new technologies) and about the capacity to live in a multi-faceted world as active and responsible citizens (p. 31).

In the same vein, Trilling and Fadel (2009) propose two sets of core skills that top the list for twenty-first century jobs, namely: the ability to quickly apply new knowledge; and knowing how to apply twenty-first century core skills (i.e., problem solving, communication, teamwork, use of technology, innovation, etc.) (Trilling and Fadel, 2009, p. 11).

The report Student Profile on Leaving Compulsory Schooling was drawn up to serve as a political guideline for educational organization and to contribute "to the convergence and articulation of decisions inherent to the various dimensions of curriculum" (Ministério da Educação, 2017, p. 8). It defended a humanist approach that assumes that the biggest challenge facing schools is to prepare our children and young people for an uncertain future. Ten categories of skills are presented that must be developed throughout all academic disciplines, namely: languages and reading; information and communication; reasoning and problem solving; critical and creative thinking; interpersonal relationships; personal development and autonomy; well-being, health and the environment; aesthetic and artistic sensibility; scientific, technical and technological knowledge; and awareness and mastery of the body. Sousa-Pereira and Leite (2019) posit that the Student Profile on Leaving Compulsory Schooling will lead to changes in pedagogical practices that will "promote critical thinking, autonomy, solidarity and attention to others, the ability to make decisions, and to live in a pluralistic and ever-changing society" (p. 120).

Schools, therefore, face a major challenge. It is in schools that our children and young people spend most of the day; it is school that exerts a major influence on their socialization and that poses for them increasing cognitive, social, and emotional challenges (Durlak et al., 2011). The need arises to devise programs that nurture young people's socio-emotional and creative skills in schools. A bibliometric study of the implementation of Social
Emotional Learning (SEL) programs in Portuguese schools concluded that such programs were few in number and that most of said studies stemmed primarily from academic research (Cristóvão et al., 2017). We are not attempting to argue that socio-emotional skills are not taught in schools, but that, as stated by Pinto and Raimundo (2016) "the challenge is to do so intentionally, effectively and positively” (p. 18). If we accept the assumption that intentionality is necessary, our attention is called to the importance of teachers' roles in nurturing the development of socio-emotional and creative skills as well as the importance of emotion in teaching practice. Research has pointed out the close relationship between teachers' socio-emotional skills and the effectiveness and quality of the teaching-learning process, in addition to the development of students' socio-emotional skills (Cejudo and López-Delgado, 2017, p. 30).

Thus, it is opportune to look into the perceptions of teachers who have had the opportunity, for the first time in their careers, to be trained in developing socio-emotional and creative skills and to put into practice programs for promoting these skills in their students. Learning about the experience of these teachers will enable us to highlight the importance of SEL programs and the need to implement them in schools, as it calls attention to the benefits that have arisen for both teachers and students.

\section{Importance of Implementing SEL Programs in Schools}

Interest in nurturing socio-emotional skills in schools has been increasing due an awareness that they are fundamental for student success, not only in school but later in adulthood. Research has confirmed that emotions can facilitate or hinder children's academic engagement, commitment, and ultimate school success since relationships and emotional processes affect how and what we learn (Elias et al., 1997).

The Socio-Emotional Learning (SEL) concept emerged in the 1990s by way of the work Elias et al. who defined it as:

\footnotetext{
"the ability to understand, manage, and express the social and emotional aspects of one's life in ways that enable successful management of life. tasks such as learning, forming relationships, solving everyday problems, and adapting to the complex demands of growth and development." (Elias et al., 1997, p. 2)
}

SEL focuses on encouraging children and youth to discover and develop their talents and potential (Elias et al., 2003).

In 1994, the Collaborative Consortium for Academic, Social and Emotional Learning (CASEL) was founded to establish highquality socio-emotional learning based on empirical evidence, and to promote the inclusion of SEL as an integral part of schoolbased education from preschool through secondary. SEL has become a key reference for research and intervention.

Collaborative for Academic Social and Emotional Learning (CASEL) $(2012,2016)$ posits that socio-emotional skills are cognitive, affective and behavioral in nature, so SEL Programs should develop five main domains: (1) Self-awareness skills refer to the ability to understand one's own emotions, personal goals, and values. This includes accurately assessing one's strengths and limitations and possessing a well-grounded sense 
of confidence and optimism. (2) Self-management skills deal with the ability to regulate one's emotions and behaviors. This includes managing stress, controlling impulses, and setting and working toward achieving personal and academic goals. (3) Social awareness skills pertain to the ability to see things from the perspective of people from different cultures and backgrounds. (4) Relationship skills are those tools that children need to establish and maintain healthy and rewarding relationships; and, (5) Skills in responsible decisionmaking concern the ability to consider ethical standards, safety concerns, and accurate behavioral norms for risky behaviors, so as to be realistically able to evaluate the consequences of various actions, and to take the health and well-being of oneself and others into consideration (Collaborative for Academic Social and Emotional Learning (CASEL), 2003). SEL is, thus, a conceptual framework for developing and encouraging social, emotional and academic skills in children and young people.

Several studies have found that SEL programs have very positively affected not only the acquisition of socio-emotional skills but have also led to improvements in students' psychosocial adaptation, attitudes and school outcomes, while also reducing disruptive behavior. A meta-analysis of 213 SEL programs revealed that they had a positive impact on school environments and promoted a range of academic, social and emotional benefits for students, including: 1) better academic performance (11 percentage points higher for SEL vs. non-SEL students); and, (2) better attitudes and behaviors (greater motivation to learn and commitment to school, more time devoted to school work and better classroom behavior; fewer instances of disruptive behaviors: fewer acts of aggression, delinquency and disciplinary processes in the classroom; reduced emotional stress: fewer reports of depression, anxiety, tension and social isolation) (Durlak et al., 2011). More recently, Corcoran et al. (2018) elaborated a systematic review and a metaanalysis comprehending 50 years of research. The review explored studies regarding the effects of school-based, from pre-kindergarten to high school, SEL interventions, on reading, mathematics, and science achievement. The results of this systematic review shows that SEL had a positive effect on reading $(\mathrm{ES}=+0.25)$, mathematics $(\mathrm{ES}=+0.26)$, and science (ES $=+0.19)$ when compared to traditional methods. These results were consistent with the results of the previous study.

Four characteristics must be present in order to ensure that SEL is effective in promoting socio-emotional skills, namely, the program must be: (1) sequenced, i.e., include a set of coordinated and connected activities designed to promote skill development; (2) active, which is to say that they must help students master new skills; (3) focused, so it must enhance students' personal and social skills development; and it must be (4) explicit, thereby targeting specific social and emotional skills (Weissberg et al., 2015). Promoting the development of students' socio-emotional skills in the classroom involves teaching socioemotional skills, giving students the opportunity to practice and improve these skills and to apply them in various everyday situations (Weissberg et al., 2015, p. 9).

\section{The Importance of Teachers in Promoting SEL}

"Most successful people had at least one teacher who made a real difference in their life - because the teacher acted as a role model, or took a genuine interest in the student's welfare and future, or provided emotional support when the student needed it." Schleicher (2018, p. 257)

Teaching and learning in schools has a strong social, emotional and academic component (Zins et al., 2004). Fernández-Berrocal and Pacheco (2009) state that one of the school's missions in the twenty-first century is to educate future generations emotionally. In our opinion, teachers and educators are students' main emotional leaders. Moreover, the foundation for promoting emotional balance within their groups is the students' ability to recognize, understand and manage their emotions. Teachers, especially primary school teachers, often serve as a highly important affective and emotional role model for students (Extremera and Fernández-Berrocal, 2004). The relationship between teachers and students is of utmost importance. Results from one large body of research have indicated that the presence of positive and supportive relationships between students and teachers promotes the long-term development of better school outcomes and reduced instances of problem behaviors (Williford and Wolcott, 2015, p. 231).

Schonert-Reicht (2017) believes that teachers are the major driving force behind SEL programs in schools and in the classroom. For the author to successfully implement an SEL program, we had to have a safe, supportive, and protective school atmosphere so that students could feel confident discussing and requesting support for their perceived needs. This positive atmosphere comprises low levels of conflict and disruptive behavior, respectful communication, proper expression of emotions, interest and focus on tasks, and support and responsiveness to individual differences and student needs (La Paro and Pianta, 2003). Worse behaviors and lessened interest in classroom activities have been found in classrooms where teachers lack the resources to manage the social and emotional challenges that occur (Marzano et al., 2003). Teachers, thus, must be able to not only explicitly teach socio-emotional skills but they also must have the necessary portfolio of the knowledge and skills to create safe and supportive classroom environments (Schonert-Reicht, 2017).

The focus, to date, has been on promoting students' socioemotional skills. However, the issue of the importance of teacher well-being has also been raised and how it may influence students' development of SEL (Schonert-Reicht, 2017). The teaching profession entails an important emotional burden, both regarding sensitivity to the emotions of others', and the need to properly manage one's own emotions so that one might be able to contribute to the quality of interpersonal relationships within school organizations (Hargreaves, 2000).

Several investigations have shown that teaching is one of the most stressful professions among the social services sector (Montgomery and Rupp, 2005; Kyriacou, 2010). A study of more than 15,000 Portuguese teachers found that over $60 \%$ of those 
surveyed suffered from emotional exhaustion (Varela et al., 2018). It has also been found that emotionally exhausted teachers are at serious risk of becoming insensitive and feeling that they have little to offer or gain in teaching, eventually losing the spirit necessary for the job, and often creating a strict learning environment characterized by hostile measures. Results can be highly detrimental both to teachers and to students (Jennings and Greenberg, 2009, p. 492).

It is from this perspective that several authors have pointed out the importance of promoting the emotional intelligence of teachers, recognizing it as a key variable for understanding and improving teaching competence. Definitions and theoretical models about emotional intelligence abound in the literature. In short, it can be defined as the ability to identify, express, use, understand and regulate one's emotions and those of others (Salovey and Mayer, 1990; Petrides and Furnham, 2003; Bisquerra et al., 2015). Greater emotional intelligence is associated with greater emotional and social competence. Cejudo and Lópes-Delgado have stated that it seems reasonable to expect teachers with greater emotional intelligence to be more sensitive to the importance of having certain personal characteristics related to the dimensions of emotional intelligence and to ensure a quality teaching-learning process (Cejudo and López-Delgado, 2017, p. 30).

Jennings and Greenberg (2009) Prosocial Classroom Model suggests that teachers' social and emotional competence as well as their well-being affect classroom management strategies, teacher-student relationships, and their ability to implement SEL programs (Figure 1). These factors may contribute to a healthy classroom environment and, in turn, lead to students' academic and SEL success.

According to Weissberg et al. (2015), the most relevant SEL approaches involve training teachers to provide intentional classes that teach social and emotional skills. Jennings and Greenberg (2009) emphasize the importance of teachers having a greater knowledge about socio-emotional skills, so they can respond to the needs of their students. Cejudo and López-Delgado (2017) argued that teachers' socio-emotional competences should be promoted as part of the pedagogical background. Several studies have found that, when teachers become aware of the importance and need to develop socioemotional skills in the classroom, they are faced with a lack of said training or adequate means to develop SEL (Abarca et al., 2002; Suberviola-Ovejas, 2012).

\section{The Current Study}

The "Mediators for Well-being" teachers' continuous training plan is part of the 'Promoting Change in Learning-Gulbenkian XXI School Learning Communities' project (PMA-CEAG XXI) that began in the 2014/2015 school year, with cohorts of third grade students. The project was implemented in three schools from Alentejo region, in the third, fourth (primary school), fifth and sixth grades (middle school). In this study we explore the representations of all seven teachers who were involved in the first 2 years of the project.

In the words of its coordinator, the PMA-CEAG XXI project aimed "to promote improved learning by way of knowledge acquisition within the formal curriculum and to boost capacities for analytical and practical reasoning, resilience and responsibility, together with technological, emotional, social and creative skills." (Verdasca, 2016, p. 21). The PMA-CEAG XXI project was inspired by action principles laid out by Kickbush in her work, Learning for Well-being (2012). Inspired by resolutions of various international organizations (e.g., WHO, UNICEF, UNESCO), the goal of the book is to inspire, engage and empower people to make all environments more learningfriendly, and to change the way people think about children and about learning, health, education, and society. A wellbeing approach to learning should rest on five basic principles: (1) the child's perspective should be adopted; (2) each child should be encouraged to express their potential; (3) action should focus on the child's strong points and inner differences; (4) the nature and the quality of relationships should be highlighted; and (5) the approach should be holistic (Kickbush, 2012).

The "Mediators for Well-being" continuous training plan followed the development of the project and was based on the teacher's reflective development model (reflection model-in-action by Schön (2000), the training was carried out in a comprehensive context that included well-being, emotional intelligence, sustainability, community content, learning, curricular transversality, project work and digital skills. The training plan was targeted at primary school teachers participating in the PMA-CEAG XXI project. The main objective of this training plan was to promote skills and empower teachers to carry out learning for well-being. The training program lasted for two academic years and was developed along two lines: (1) three 6-h sessions brought together teachers from all three participating schools for the broad context training; and 2) in the immediate context of each school, twice-monthly, 1-h follow up sessions were held with participating teachers. The following topics were discussed at three different moments in the broad context sessions: the PMA-CEAG XXI Project was presented; the 'Learning for Well-being' model was explored; activities to develop socio-emotional and creative skills were carried out; emotional self-regulation skills were boosted; pedagogical strategies were discussed: integrative curricula and project work were looked at; work was carried out in partnership with the Educational Service of Eugénio de Almeida Foundation Museum of Contemporary Art; lessons plans were presented that would comprise part of the Emotional Literacy Program (ELP) and Creative Thinking Development Program-Flow. Within each school, teachers received specific training on socioemotional and creative skills, as well as those for implementing the ELP and Flow programs. Necessary materials were also handed out. These sessions also served as spaces for sharing and reflection.

\section{Emotional Literacy Program - ELP}

The goal of the ELP was to promote students' emotional regulation, empathy and responsible decision making. The program's main objectives were to develop and improve: (i) emotional self-awareness; (ii) emotional self-regulation; (iii) 


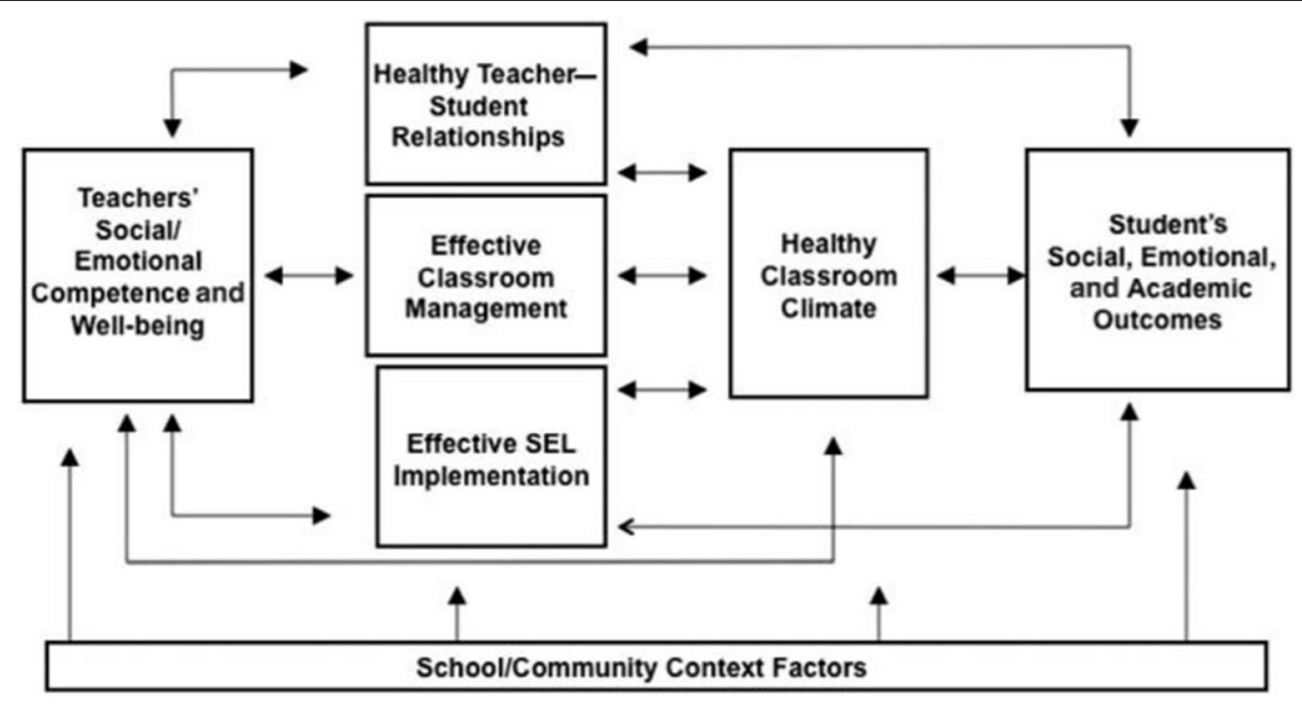

FIGURE 1 | The prosocial classroom model by Jennings and Greenberg (2009, p. 494).

social awareness; and (iv) interpersonal relationships (Cristóvão et al., 2017, p. 7762).

The ELP Program was composed of three blocks of classroom activities: (1) The basic emotions block aimed at teaching students to identify and name the six basic emotions and recognize them in themselves and others, as well as to learn to manage their emotions and consequently their behaviors; (2) Feeling activities focused on students learning the family of feelings, understanding the distinction between emotions and feelings, recognizing feelings and acquiring strategies for emotional regulation; and (3) The main objectives of the thought block were to learn the family of thoughts, to recognize thoughts and distinguish the bad from the good and to learn strategies of emotional regulation. The following methodology was followed:

According to ELP methodology, teachers received specific training on socio-emotional and creative skills, to be worked with their students at the classroom, 30-45 min per week, acting as mediators (Figure 2). On the other hand, students had some small activities to do with their families, about subjects worked under the ELP program. In this case the students perform as mediators with their families. The cyclical logic of contagion is intended to spread socio-emotional skills so that they begin to play a major role throughout the school, the families and the community. Thirty to forty-five minutes of teachers' classroom hours were allocated to ELP Program activities so that socioemotional and creative skills could be worked on.

\section{Creative Thinking Development Program-Flow}

The Flow Program aims to develop creative thinking of students and teachers through innovative pedagogical practices that promote the emotional and social characteristics essential to the creative process. In training sessions, teachers were encouraged to create projects with students that would develop skills at discovering and solving problems. The Flow program was enriched by the participation in a session of an internationally recognized artist, Nicolás Paris. The artist used practical exercises to challenge teachers: to reflect on different teaching and learning strategies; to use art as a tool to build dialogue and environments to provoke reflection; to deconstruct their practice to find new possibilities; and to use drawing as a learning tool and basic element of language. The Flow Program is based on the idea that the school is a space for cultural socialization, a space where everyday knowledge and experience that students bring to school are important in the teaching-learning process. In this way, this creative thinking development program enabled students to create a space, in the form of a mural with trees, in their classroom where they could bring their informal beings into the formal classroom.

\section{METHOD}

This descriptive-exploratory study is a qualitative approach, since it seeks to understand and interpret a phenomenon based on the meaning attributed by the study participants, namely by describing teachers' perceptions about the implementation of the socio-emotional and creative component of the PMA-CEAG XXI project. We opted for a case study as we felt it necessary to undertake a thorough analysis of a phenomenon in its natural environment and in its real context. As there are no similar situations for comparative studies, this is a unique case study which should, thus, present innovative information (Yin, 2014). It should be pointed out that the present study deals with a single case, i.e., participation in a specific research project, the PMA-CEAG XXI.

\section{Participants}

All the participants are 1st cycle teachers, from the three schools that participated in the PMA-CEAG XXI project, two primary teachers from Vidigueira (T4 and T7), and Vendas Novas School 


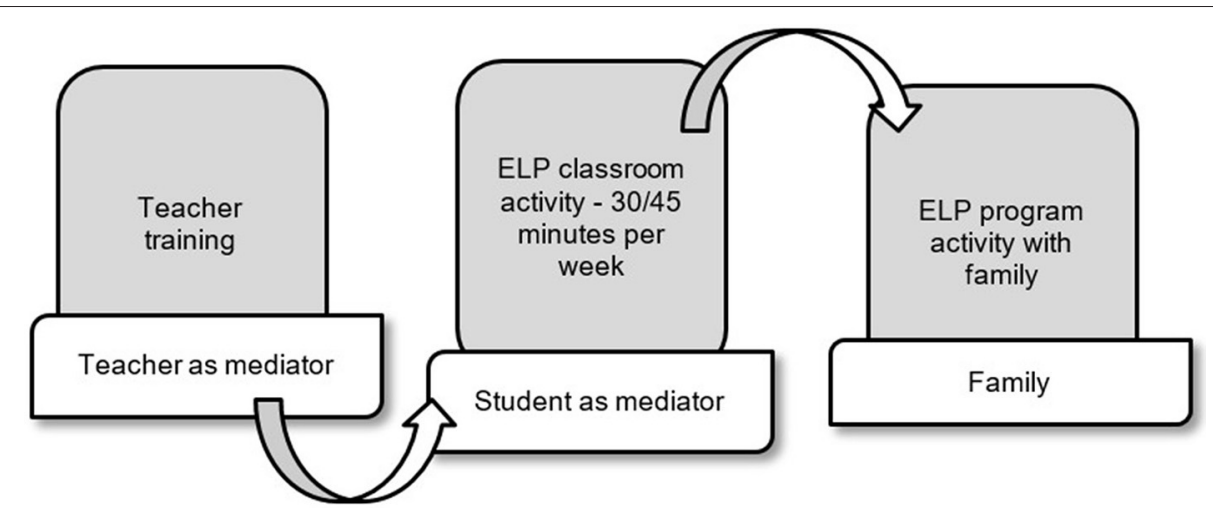

FIGURE 2 | ELP program methodology.

(teachers T5 and T6), and three primary teachers from Ponte de Sor School (Teachers T1, T2, and T3). Of the seven teachers, six were women (85.7\%) and only one was a man (14.3\%), percentages that are aligned with the overall Portuguese scenery, where the percentage of female teachers is $86.7 \%$ (PORDATA, 2018). The group is very homogeneous regarding age, with three teachers aged between 45 and 50 years old, and 4 between 50 and 55 years, all of them over 25 and under 28 years of service. We can say that this is a group with a lot of service experience.

\section{Procedure}

This study respected the principles outlined in the current Portuguese and European legislation on educational investigation, and it was approved by the Research Ethics Committee of the University of Évora. All subjects gave written informed consent. Interviews were chosen to collect data since they allow "...the social actors themselves...[to] provide the data on their conduct, opinions, desires, attitudes and expectations, which, by their nature, is almost impossible to observe from the outside." (Vilelas, 2017, p. 303). In a semi-structured interview, the investigator used both open and closed questions to provide a certain degree of freedom to the interviewer and the interviewee. The teachers were contacted by phone whereby the objectives of the interviews were presented and they were invited to participate. Seven teachers agreed to participate and the respective interviews were scheduled and conducted at the participating teachers' schools. A guide was drawn up to standardize the seven interviews and orient the interviewer. The guide was prepared in relation to the research objectives and was validated by three senior investigators. It consisted of several topics and aimed to analyze and interpret the reflections of the primary school teachers about various aspects of the implementation of the PMA-CEAG XXI project. Only those issues related to the socio-emotional and creative component were considered. Thus, teachers' opinions about several aspects of the impact of implementing the socio-emotional and creative component in the classroom were sought. We also wanted to what representations participating teachers had about promoting socio-emotional and creative skills. A member of the project's research team conducted the semi-structured interviews lasting between 40 and 60 min and which were recorded and then fully transcribed. The questions were:

- Tell me a little about what it was like for you to take part in the PMA-CEAG XXI project?

- What was it like to introduce the socio-emotional and creative component in your teaching practice?

- Did you feel comfortable working with this component with your students?

- What advantages and disadvantages do you see in introducing these components into pedagogical practice?

- What most impressed you about developing socio-emotional and creative skills?

- What do you think is needed for the development of socioemotional skills in schools?

- Are you satisfied with the training provided?

\section{Data Analysis}

Content analysis is set of techniques and systematic procedures for interpreting communications in order to make "logical and justified deductions about the origin of these messages" and it was chosen as it is considered suitable for the treatment of qualitative data (Vilelas, 2017, p. 388) It entailed using the qualitative data analysis software webQDA to interpret, systemize, and express content as per Bardin (2008). This software enables researchers to carry out their research by creating a database with either tree-diagrammed or free categories, through which information segments can be stored, encoded, indexed and classified and then retrieved and recoded (Neri de Souza et al., 2011).

\section{RESULTS}

In this study, seven questions related to the aspects of socioemotional and creative skills (CSEC) guided interviews with the seven PMACEAG-XXI teacher participants. The interviews were recorded, transcribed and subject to Bardin content analysis (Bardin, 2008). The tables and graphs below were drawn up to illustrate the results with categories and subcategories, with their respective partial and absolute frequencies of the number of mentions or Recording Units (RU). 
Four dimensions emerged from the data analysis: Impact on Pedagogical Practice; Impact on Teachers; Impact on Students; and Impact on schools. Twenty-six subcategories arose which appear in Table 1.

Overall, 401 recording units were coded, distributed among the 28 subcategories which fell into the four categories already mentioned. These categories encompass four key dimensions of the school community: teachers (key project partners); students (primary focus of the project); the school (the main but not unique venue for activities); and pedagogical practices (tool for implementing the project).

Figure 3 shows the categories that emerged from content analysis and the number of recording per category.

The category with the highest percentage of recording units was Impact on Teachers with $36.41 \%$ (146 RU), followed by Impact on Pedagogical Practice with 25.93\% (104 RU). Impact on Schools received 23.94\% (96 RU) and Impact on Students garnered $13.72 \%$ (55 RU). Six subcategories had more than 20 RU: Satisfaction with participation in the project (31 RU), Carrying out a variety of activities (28 RU), Improving the classroom atmosphere (25 RU), Contributions to [teachers'] personal development (25 RU), Greater student openness to expressing emotions (22 RU), and Need to develop CSEC in schools (21 UR).

Each of the seven teachers interviewed contributed in different proportions to the various subcategories, as is illustrated in Figure 4.

Teachers T2 (105 RU) and T3 (109 RU) contributed the most recording units overall. These were the teachers who had showed the least enthusiasm for CSEC at the beginning of the project but who gained the greatest interest once they realized the importance of developing these skills in the classroom. As teacher T2 said, "After a while we realized that the role of emotions made perfect sense and was just as important, if not more important, than the technological part." Table 2 illustrates the four main categories that emerged from the data analysis.

Table 2 illustrates that more recording units were found in the category Impact on Teachers for participants T1, T3, and T6.

\section{Impact on Teachers}

Impact on Teachers received $145 \mathrm{RU}$, spread across eight subcategories, namely: Need for more training; Overcoming initial expectations; Promoting teachers' wellbeing; Strengthening teacher-student relationship; Improved understanding of students' emotional state; Improved understanding of the importance of CSECs; Contribution to personal development; Satisfaction with project participation.

Figure 5 shows the predominance of the subcategory Satisfaction with project participation $(f=31)$. In the words of one teacher "I have been saying, these 2 years, the 2 years I participated in the project, I think they were the best 2 years of my career, the best time of my career." (T1) Teachers also pointed out the importance of participating in the project for their personal development $(f=25)$. One teacher stated " $(\ldots)$ the project that allowed us to make major changes as people for 2 years." (T2) Another said, "I grew a lot as a teacher, but also as a person." (T3) Better understanding of the importance of CSEC $(f=18)$ also stood out. As one teacher noted, "I am aware that the socio-emotional skills activities that we carried out are very important." (T5) Finally, the subcategory Strengthening teacher-student relationship was also mentioned frequently $(f=$ 16). In the words of one teacher, "Although I always had a good relationship with the other kids, with other classes, I might say that it was more intense with these kids." (T16).

\section{Impact on Pedagogical Practice}

Impacts on Pedagogical Practice received 104 recording units (Figure 6), divided among the following six subcategories: Promoting strategies for emotional regulation; Increase in time allocated to CSEC; Developing activities targeted to promoting CSEC; Importance of training received; Improved classroom climate and Carrying out a variety of activities.

The teachers stressed Carrying out a variety of activities $(f=28)$ and Improved classroom atmosphere $(f=25)$ as the subcategories that had the greatest impact on pedagogical practice. One teacher said, "There were a lot of things that I did this year, building the mural that they wanted to convey their emotions was really interesting." (T3) Regarding the classroom atmosphere, one participant pointed out, "The working atmosphere, our classroom atmosphere was a climate of respect that I want to keep going," (T2) while another said "It was very happy, very happy." (T3).

\section{Impact on the School Community}

The Impact on the School Community category, with 96 recording units, is divided into eight subcategories: Need for greater management guidance; Increased family-school involvement; CSEC impact on other primary school classes; Residual impact on school dynamics; Principal's support; Family satisfaction with the project; Need to train all teachers and Need to carry out CSEC in schools (Figure 7).

After participating in the project and implementing the ELP and Flow programs, teachers became aware of the Need to develop CSEC in schools. As one teacher put it, "Socio-emotional skills need to be worked more or less systematically over time." (T7) Another said, "I think that socio-emotional skill activities should start in pre-school and I think this component is very important in primary school." (T6) In regard to the need to carry out CSECs in schools, teachers point to the necessity for teachers to receive training in this area. "We've never had training, well, in this area. This area has never been... emotional intelligence has always been something that has been ignored..." (T3) or, as another participant said, "It's a pity we don't have a lot of support, a lot of training in this area." (T6).

\section{Impact on Students}

The Impact on Students category, with 55 recording units, was broken down into the following five subcategories: Greater openness to expressing emotion, Developing emotional skills; Promoting mutual support; Prevention of disruptive behavior, and Contribution to personal development (Figure 8).

The teachers stressed that they had noticed in their students a "Greater openness to expressing their emotions" $(f=22)$. One teacher stated "(...) it was their openness, putting themselves out there, in front of me and in front of their classmates that impressed me the most," (T4) while another said "(...) 
TABLE 1 | Registration units $(F=379)$ by category and subcategory for the seven teachers.

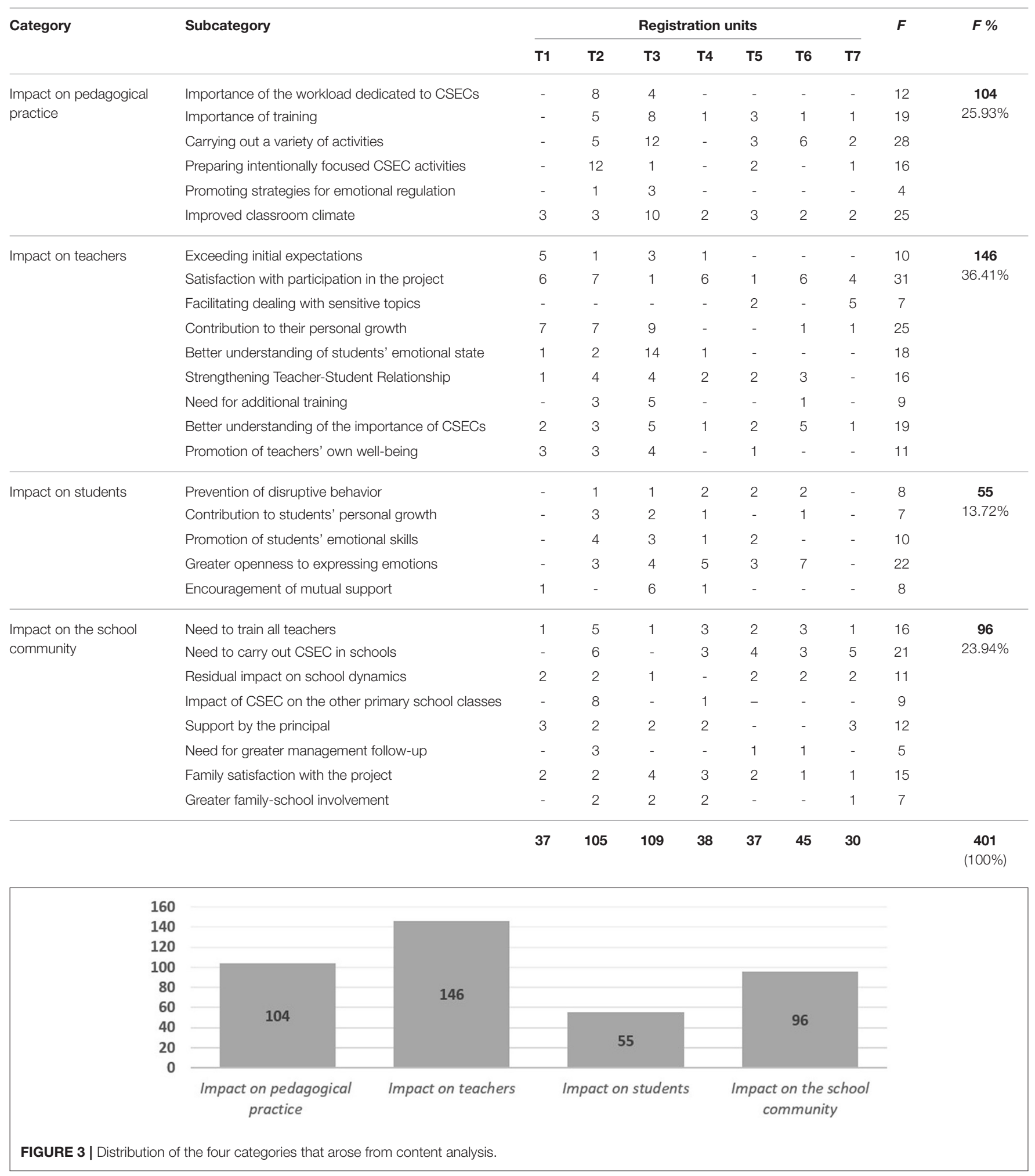

but I found the openness on their part very interesting" (T5). Promotion of emotional skills was also emphasized by the teachers, as one put it, "I think it was the first time I realized that these kids were perfectly aware of what sadness was" (T3).

\section{DISCUSSION}

The topics of socio-emotional and creative skills have mobilized many of the educators and researchers in the fields of 


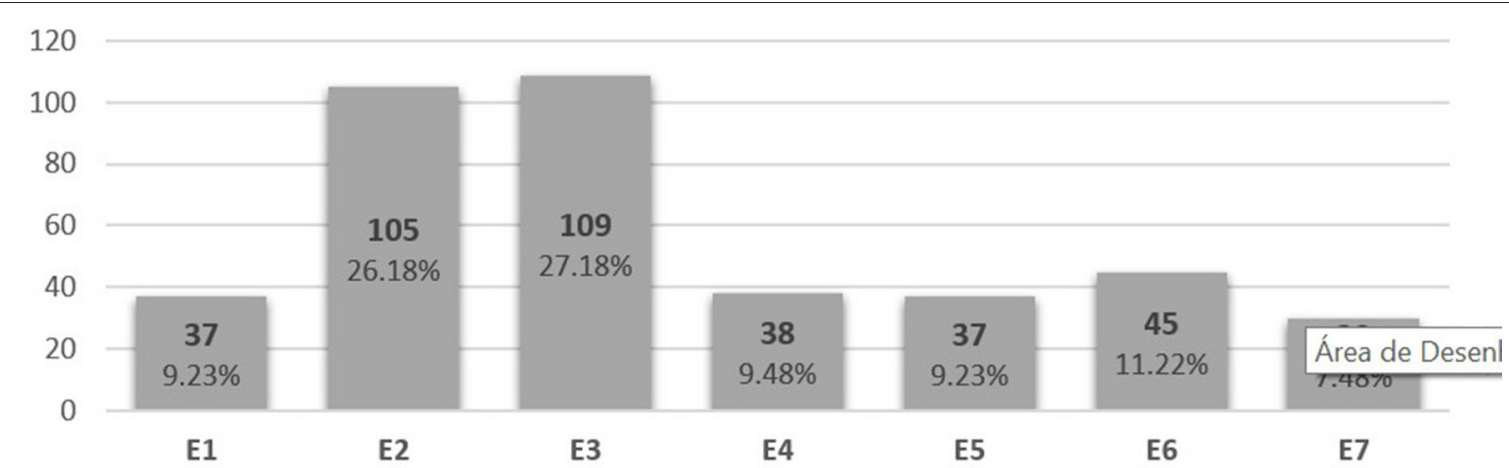

FIGURE 4 | Distribution of number of recording units by participant.

TABLE 2 | Distribution of the number of recording units of the various categories by participant.

\begin{tabular}{|c|c|c|c|c|c|c|c|}
\hline Category & \multicolumn{7}{|c|}{ Participant } \\
\hline Impact on teachers & $\begin{array}{c}25 \\
67.58 \%\end{array}$ & $\begin{array}{c}30 \\
28.57\end{array}$ & $\begin{array}{c}45 \\
41.28 \%\end{array}$ & $\begin{array}{c}11 \\
28.95 \%\end{array}$ & $\begin{array}{c}8 \\
21.62 \%\end{array}$ & $\begin{array}{c}16 \\
35.56 \%\end{array}$ & $\begin{array}{c}11 \\
36.67 \%\end{array}$ \\
\hline Impact on the school community & $\begin{array}{c}8 \\
21.62 \%\end{array}$ & $\begin{array}{c}30 \\
28.57 \%\end{array}$ & $\begin{array}{c}10 \\
9.18 \%\end{array}$ & $\begin{array}{c}14 \\
36.84 \%\end{array}$ & $\begin{array}{c}11 \\
29.73 \%\end{array}$ & $\begin{array}{c}10 \\
22.22 \%\end{array}$ & $\begin{array}{c}13 \\
43.33 \%\end{array}$ \\
\hline
\end{tabular}

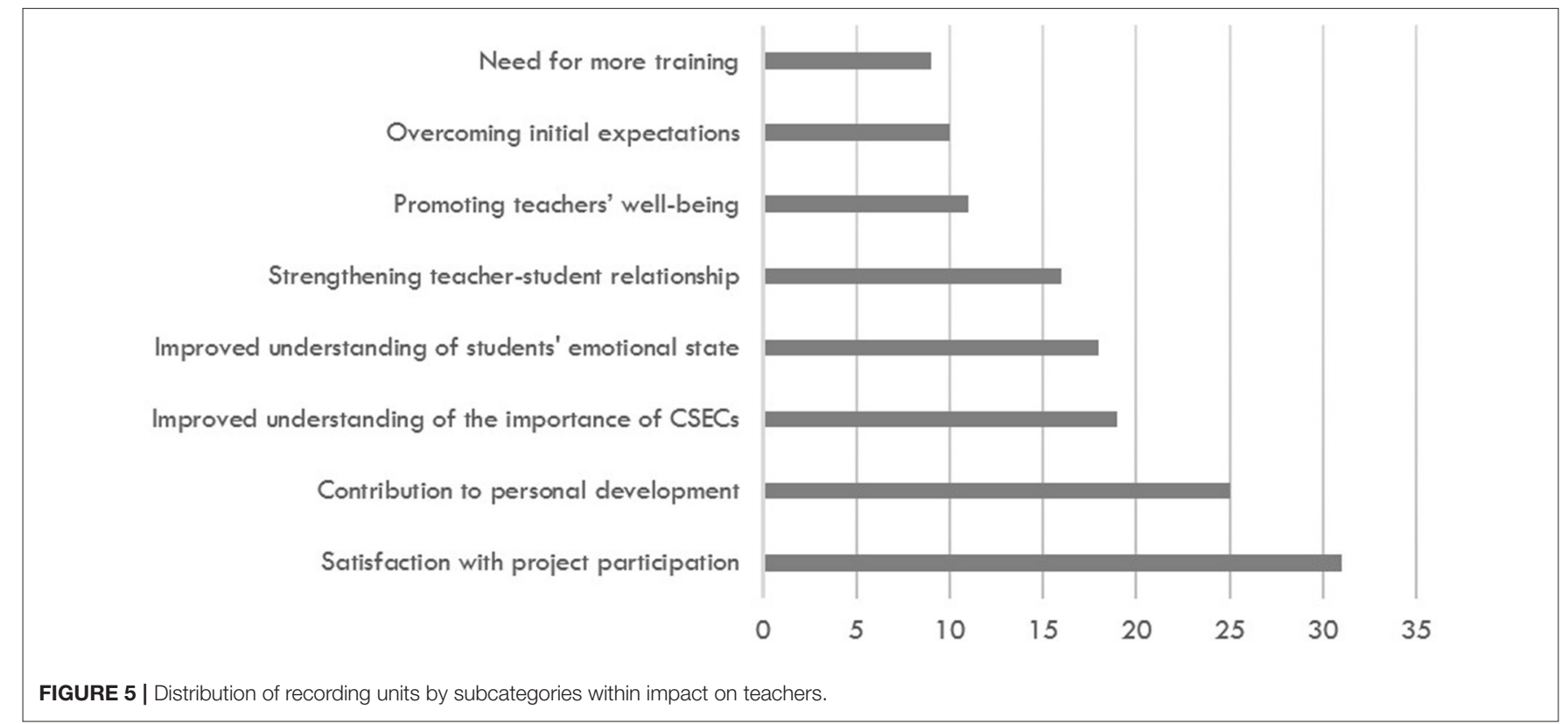

education and psychology. In this study we tried to interpret and understand, using the perceptions of seven teachers who started this project, the development of the socio-emotional skills and creativity as part of the PMA-CEAG XXI initiative. Our goal was to understand which aspects teachers valued the most and, among them, which dimensions added value to the day-to-day life of teachers and students, as well as to identify what improvements are needed and to relate them to the training received and the work carried out in the classroom. 


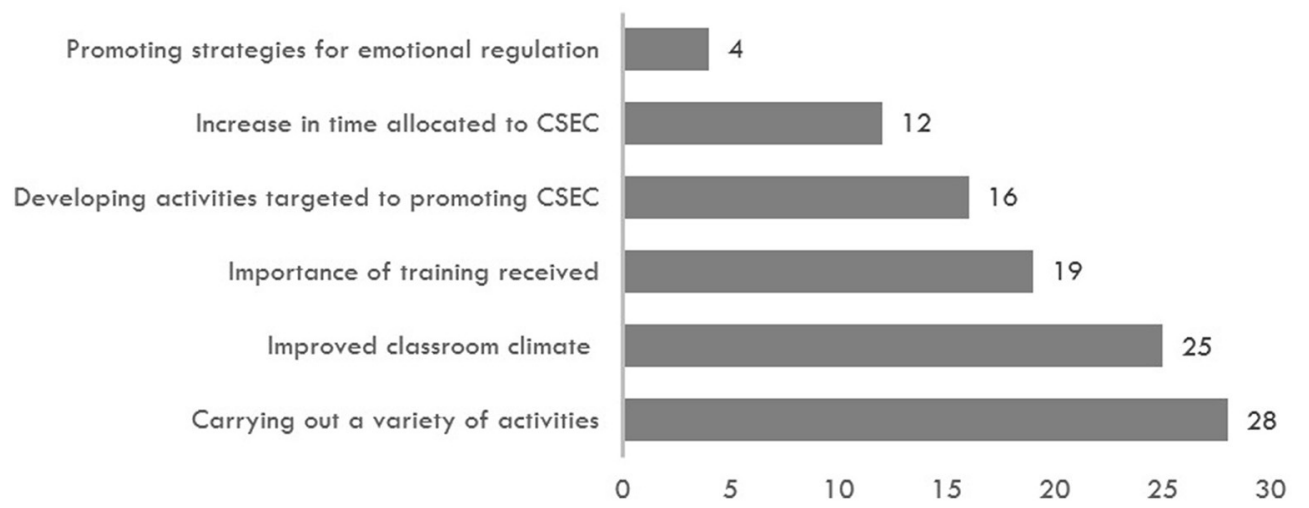

FIGURE 6 | Subcategorization of recording units within impacts on pedagogical practice.

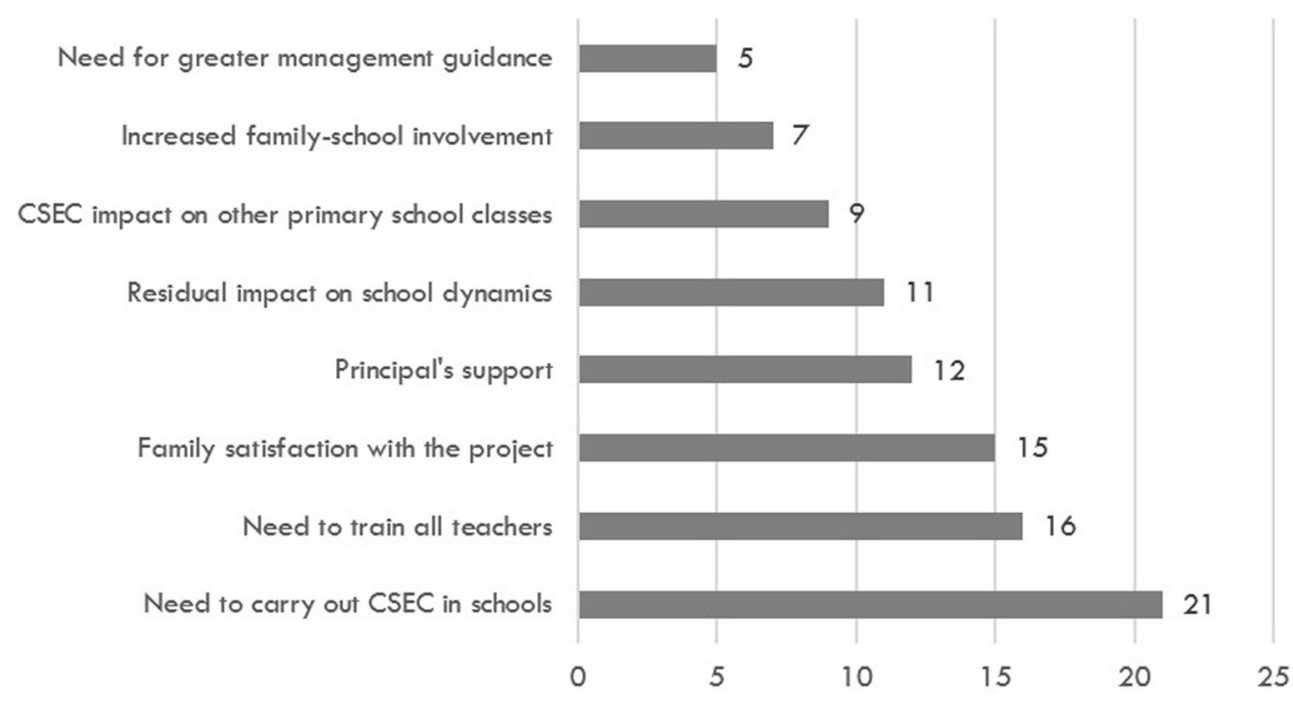

FIGURE 7 | Subcategorization of recording units within impact on the school community.

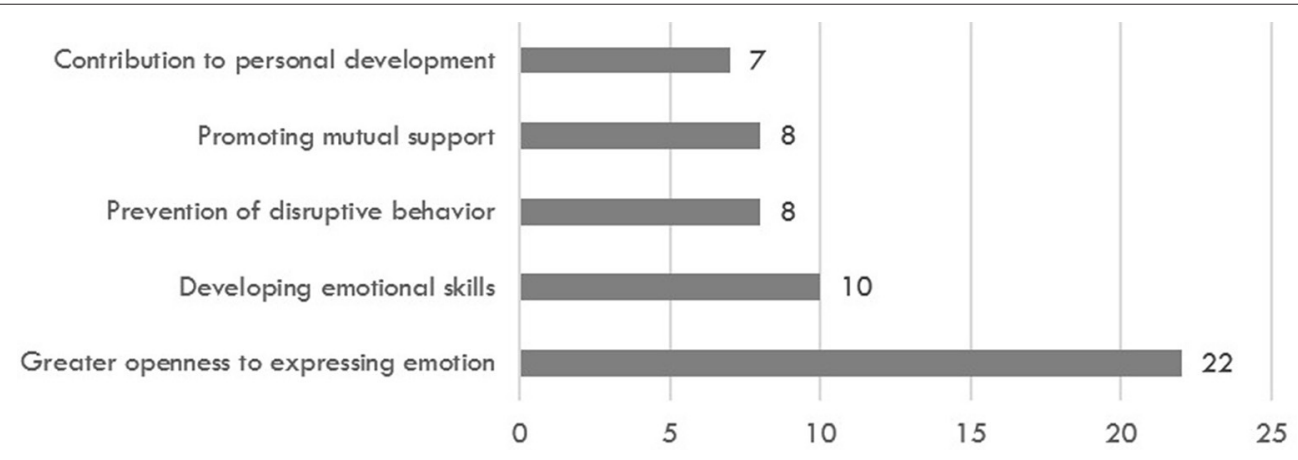

FIGURE 8 | Subcategorization of recording units within impact on impact on students.

The results unequivocally pointed to the existence of four representative dimensions of teachers' responses: the impact on themselves; the impact on students; the impact on teaching and learning practice; and the impact on the school community. In their words, the implementation of CSEC has generally been very positive. Only two of the twenty-eight subcategories pointed to less successful aspects: residual impact on school dynamics, and the need for greater attention by the principal's office. Regarding 
the latter question, it should be pointed out that the three teachers who mentioned it are from the same school, and those from the other two schools did not bring this topic up. It is also relevant that T2 stated that they had the support of school management whenever they requested it, however, they did not feel any support arose unsolicited from the principal's office. Regarding the Residual impact on the dynamics of the school, the teachers themselves pointed out that, as this was a pilot research project, with funding for only seven classes, there was no direct intention to work with other classes and teachers. This does not mean that it would have been impossible. This issue was discussed during the project implementation. It would have to have been introduced by the research team. It needed to have arisen naturally but that did not happen. However, it should be noted that, although nonparticipating teachers and students did not actively participate in the design of the activities, in many cases, they were participants and spectators. Along the same vein it would be beneficial for all teachers to receive CSEC training, so that, due to their importance, these skills might be developed and such activities carried out. The students' families were satisfied, and this opinion created greater involvement between the families and the school.

Pedagogical practice also benefited. The teachers pointed out the variety of activities focused on CSEC with clear and multidisciplinary objectives, which led to an improvement in the classroom atmosphere, while many activities also took place outside the classroom and even outside the school. The teachers were of the opinion that this improvement was not independent of the additional time per week allocated to work specifically on these skills, nor of the training received. These aspects were considered important by six of the seven teachers. Participants perceptions indicate that working on CSEC enabled students to develop greater openness to expressing their emotions and the ability to do so more skillfully, which also improved their behavior and mutual support, thus contributing to their personal development.

Finally, in relation to themselves, the teachers were highly satisfied with their participation in the project, which exceeded their expectations. They now have greater understanding of the importance of CSEC. Their own well-being and personal development were boosted. Their relationships with their students were also strengthened, at times due to their own better understanding of students' emotional states.

In conclusion, we can argue that impacting teachers impacts students as well, while also improving the way the teaching and learning process takes place. The importance of academic

\section{REFERENCES}

Abarca, M., Marzo, I., and Sala, L. (2002). La educación emocional en la práctica educativa de primaria. Bordón 54, 505-518.

Bardin, L. (2008). Análise de Conteúdo. Lisboa: Edições 70. doi: 10.1016/S1773-035X(08)74523-4

Bisquerra, R., Pérez-González, J. C., and García Navarro, E. (2015). Inteligencia Emocional en Educación. Madrid: Síntesis.

Cejudo, J., and López-Delgado, M. L. (2017). Importancia de la inteligencia emocional en la práctica docente: un estudio training in emotional intelligence (in particular) and the development of social skills (in general) associated with the multiple aspects of creativity has proved to add value to the daily practice of these teachers, who are in favor of additional training for themselves and their peers. They feel that these fields promote the personal development of teachers and students, making them both better human beings and more emotionally skilled people, while also contributing concrete improvements to the teaching and learning process. With this study it became clear the need to support the personal and professional development of teachers. Coaching, mentoring and other developing areas need to be brought into education, so that teachers develop soft skills and deepen the knowledge of their students and the passion for the profession. Further studies to analyze teachers' perceptions about the effectiveness of SEL programs in classroom context would be important. In addition, studies are needed to better understand how gender, age, prior experience, and academic training can influence the outcomes of SEL programs.

\section{LIMITATIONS}

The sample is small and idiosyncratic, and there is no way to establish the probability that data is representative of some larger population. The study focuses only on seven teachers and only one of the teachers is a man and all participating have over 25 years of professional experience and have over 45 years old, leaving open the comparisons with young teachers and male teachers to future studies.

\section{DATA AVAILABILITY STATEMENT}

The datasets generated for this study are available on request to the corresponding author.

\section{AUTHOR CONTRIBUTIONS}

AMC: conceptualization, methodology, and writing. AAC and JV: review and supervision.

\section{FUNDING}

This work was supported by Fundation Calouste Gulbenkian as part of the Project PMA-CEAG-XXI. AMC was supported by a Ph.D. grant from Fundation Calouste Gulbenkian as part of the Project CEAG-XXI funded by the same institution. 
Collaborative for Academic Social and Emotional Learning (CASEL) (2016). SEL Impact. Retrieved from http://www.casel.org/impact/ (accessed May 13, 2019).

Corcoran, R., Cheung, A., Kim, E., and and, Xie, C. (2018). Effective universal school-based social and emotional learning programs for improving academic achievement: a systematic review and meta-analysis of 50 years of research. Edu. Res. Rev. 25, 56-72. doi: 10.1016/j.edurev.2017. 12.001

Cristóvão, A., Candeias, A., and Verdasca, J. (2017). Social and emotional learning and academic achievement in Portuguese schools: a bibliometric Study. Front. Psychol. 8:1913. doi: 10.3389/fpsyg.2017.01913

Durlak, J., Weissberg, R., Dymnicki, A., Taylor, R., and Schellinger, K. (2011). The impact of enhancing students' social and emotional learning: a metaanalysis of school-based universal interventions. J. Child Dev. 82, 405-432. doi: 10.1111/j.1467-8624.2010.01564.x

Elias, M. J., Zins, J. E., Graczyk, P., and Weissberg, R. (2003). Implementation, sustainability, and scaling up of social emotional and academic innovations in public schools. School Psychol. Rev. 3, 303-319.

Elias, M. J., Zins, J. E., Weissberg, R. P., Frey, K. S., Greenberg, M. T., Haynes, N. M., et al. (1997). Promoting Social and Emotional Learning: Guidelines for Educators. Alexandria: Association for Supervision and Curriculum Development.

Extremera, N., and Fernández-Berrocal, P. (2004). La importancia de desarrollar la inteligencia emocional en el profesorado. Rev. Iberoam. Educ. 33, 1-10.

Fernández-Berrocal, P., and Pacheco, N. E. (2009). La inteligencia emocional como una habilidad esencial en la escuela. Rev. Iberoam. Educ. 29, 1-6. doi: $10.35362 /$ rie 2912869

Hargreaves, A. (2000). Mixed emotions: teachers' perceptions of their interactions with students. Teach. Teach. Educ. 16, 811-826. doi: 10.1016/S0742-051X(00)00028-7

Jennings, P. A., and Greenberg, M. T. (2009). The prosocial classroom: teacher social and emotional competence in relation to student and classroom outcomes. Rev. Educ. Res. 79, 491-525. doi: 10.3102/00346543083 25693

Kickbush, I. (2012). Aprender para o Bem-Estar: uma prioridade politica para as crianças e os jovens da europa. Um processo para a mudança. Lisboa: Fundação Calouste Gulbenkian.

Kyriacou, C. (2010). Teacher Stress: Directions for future research. Educ. Rev. 53, 27-35. doi: 10.1080/00131910120033628

La Paro, K. M., and Pianta, R. C. (2003). CLASS: Classroom Assessment Scoring System. Charlottesville, VA: University of Virginia Press.

Marzano, R. J., Marzano, J. S., and Pickering, D. (2003). Classroom Management that Works: Research-Based Strategies for Every Teacher. Alexandria, VA: Association for Supervision and Curriculum Development.

Ministério da Educação (2017). Perfil Dos Alunos à Saída da Escolaridade Obrigatória. Lisboa: Ministério da Educação.

Montgomery, C., and Rupp, A. (2005). A meta-analysis for exploring the diverse causes and effects of stress in teachers. Can. J. Educ. 28, 461-488. doi: $10.2307 / 4126479$

Neri de Souza, F., Costa, A., and Moreira, A. (2011). Questionamento no processo de análise de dados qualitativos em apoio do software WebQDA [Questioning in the qualitative data analysis process in support of WebQDA software]. Eduser: Revista de Educação 3, 19-30. doi: 10.34620/eduser. v3i1.28

Petrides, K. V., and Furnham, A. (2003). Trait emotional intelligence: behavioural validation in two studies of emotion recognition and reactivity to mood induction. Eur. J. Pers. 17, 39-57. doi: 10.1002/per.466

Pinto, A., and Raimundo, R. (2016). "Socio-emotional learning framework: evolution and challenges," in Evaluation and Promotion of Socioemotional Skills in Portugal, eds A. Pinto and R. Raimundo (Lisboa: Coisas de Ler), 15-36.

PORDATA (2018). Docentes do sexo feminino em \% dos docentes em exercício nos ensinos pré-escolar, básico e secundário: total e por nivel de ensino. Lisboa: FFMS.
Retrieved from www.pordata.pt/Portugal/Docentes+do+sexo+feminino+em + percentagem+dos+docentes+em+exerc\%C3\%ADcio+nos+ensinos+pr\%C3 $\% \mathrm{~A} 9+\mathrm{escolar}+\mathrm{+b} \% \mathrm{C} 3 \% \mathrm{~A} 1$ sico+e+secund\%C3\%A1 rio+total+e+por+n\%C3 \%ADvel+de+ensino-782 (accessed November 11, 2019).

Salovey, P., and Mayer, J. D. (1990). Emotional intelligence. Imagination Cogn Person. 9, 185-211. doi: 10.2190/DUGG-P24E-52WK-6CDG

Schleicher, A. (2018). World Class: How to build a 21st-century School System, Strong Performers and Successful Reformers in Education. Paris: OECD Publishing.

Schön, D. A. (2000). Educando o profissional reflexivo: um novo design para o ensino e a aprendizagem. Porto Alegre: Artes Médicas Sul.

Schonert-Reicht, K. (2017). Social and emotional learning and teachers. Future Child. 27, 137-155. doi: 10.1353/foc.2017.0007

Sousa-Pereira, F., and Leite, C. (2019). Students profile leaving compulsory educationpolicy and challenges for teacher training. Rev. Educação Ciência e Cultura 4, 113-122. doi: 10.18316/recc.v24i1.5603

Suberviola-Ovejas, I. (2012). Auto-percepción del profesorado sobre su formación en educación emocional. Rev. Comun. Vivat Acad. 1154-1167. doi: 10.15178/va.2011.117E.1154-1167

Trilling, B., and Fadel, C. (2009). 21st Century Skills: Learning for Life in our Times. San Francisco, CA: John Wiley \& Sons.

Varela, R., Santa, R., Silveira, H., Matos, C., Rolo, D., and Leher, R. (2018). Inquérito nacional sobre as condições de vida e trabalho na educação em portugal (INCVTE). Lisboa.

Verdasca, J. (2016). "Inclusão, Inovação e Bem-Estar: a experiência das comunidades escolares de aprendizagem Gulbenkian XX," in Promoção do Sucesso Educativo: estratégias de Inclusão, Inovação e Melhoria - Conhecimento, formação e ação, eds C. Palmeirão and J. Alves (Porto: Universidade Católica Editora), 9-39.

Vilelas, J. (2017). Investigação: o processo de construção do conhecimento. Lisboa: Edições Sílabo.

Weissberg, R., Durlak, J., Domitrovich, C., and Gullotta, T. (2015). "Social and emotional learning: past, present, and future," in Handbook of Social and Emotional Learning, eds J. Durlak, C. Domitrovich, R. Weissberg, and T. Gullotta (New York, NY: The Guilford Press), 3-19.

Williford, A. P., and Wolcott, C. S. (2015). "SEL and Student-Teacher Relationships," in Handbook of Social and Emotional Learning, eds J. Durlak, C. Domitrovich, R. Weissberg, and T. Gullotta (New York, NY: The Guilford Press), 181-196.

World Economic Forum (2016). The Future of Jobs Employment, Skills and Workforce Strategy for the Fourth Industrial Revolution. Global Challenge Insight Report. World Economic Forum.

Yin, R. (2014). Case Study Research Design and Methods, 5th Edn. Thousand Oaks, CA: Sage.

Zins, J., Bloodworth, M., Weissberg, R., and Walberg, H. (2004). "The scientific base linking social and emotional learning to school success," in Building Academic Success on Social and Emotional Learning: What Does the Research Say? eds J. E. Zins, R. P. Weissberg, M. C. Wang, and H. J.Walberg (NewYork, NY: Teachers College Press), 3-22.

Conflict of Interest: The authors declare that the research was conducted in the absence of any commercial or financial relationships that could be construed as a potential conflict of interest.

Copyright $(2020$ Cristóvão, Candeias and Verdasca. This is an open-access article distributed under the terms of the Creative Commons Attribution License (CC BY). The use, distribution or reproduction in other forums is permitted, provided the original author(s) and the copyright owner(s) are credited and that the original publication in this journal is cited, in accordance with accepted academic practice. No use, distribution or reproduction is permitted which does not comply with these terms. 